\title{
Evaluation of the Antibacterial Effect of MTAD and Sodium Hypochlorite against Endodontic Pathogens
}

\author{
Ghada Y. Abdul Rahman ${ }^{1,}$, Karam Ahmed Thiab ${ }^{2}$, Rasha M. Al-Shamaa ${ }^{2}$ \\ ${ }^{1}$ Department of Dental Basic Science, College Of Dentistry, Mosul University, Iraq \\ ${ }^{2}$ Department of Conservative Dentistry, College of Dentistry, Mosul University, Iraq \\ *Corresponding author: ghadakahwaji@gmail.com
}

Received March 28, 2014; Revised April 17, 2014; Accepted April 17, 2014

\begin{abstract}
The purpose of this investigation was to compare the efficacy of Biopure MTAD versus $5.25 \% \mathrm{NaOCl}$ as irrigant solutions for root canals infected with E. faecalis and Strept. Mutans. Materials and Methods: Forty extracted human single-rooted lower premolar teeth are decoronated at the cemento-enamel junction (CEJ). The roots will instrumented by k-file till size 40 then these teeth will contaminated by bacteria in brain heart infusion for 48 hrs. The samples will divide into 3 groups (MTAD, NaOCl and normal saline). Dentin chips will removed from the canal with sterile low speed hand piece round bur the collected dentin chips will transfer by BHI and culture on the media and the growing colonies will count and record as colonies forming unit (CFU). Results: The antibacterial activity of Biopure MTAD was significantly differ from that of $5.25 \% \mathrm{NaOCl}$ and distilled water.Conclusion: Biopure MTAD has the strongest antibacterial effect against E.faecalis and Strept. mutans than $5.25 \% \mathrm{NaOCl}$ and distilled water.
\end{abstract}

\section{Keywords: disinfection of root canal, Enterococcus faecalis, MTAD}

Cite This Article: Ghada Y. Abdul Rahman, Karam Ahmed Thiab, and Rasha M. Al-Shamaa, "Evaluation of the Antibacterial Effect of MTAD and Sodium Hypochlorite against Endodontic Pathogens." International Journal of Dental Sciences and Research, vol. 2, no. 2 (2014): 47-49. doi: 10.12691/ijdsr-2-2-5.

\section{Introduction}

Root canal morphology is complex and contains numerous ramifications and anatomical irregularities. The microorganisms in root canals not only invade the anatomic irregularities of the root canal system but are also present in the dentinal tubules. Persistent endodontic disease after root canal therapy may be caused by bacteria in dentinal tubules. Current techniques of root canal debridement may leave areas of the root canal system completely untouched by the instruments [1].

It has also been shown that mechanical instrumentation without irrigation reduces but does not predictably eliminate bacteria in the canal. Thus, a root canal irrigant is needed to aid in the debridement of the canals.Various concentrations of sodium hypochlorite $(\mathrm{NaOCl})$ have been used as root canal irrigants for many decades. The main advantages of $\mathrm{NaOCl}$ are its ability to dissolve necrotic tissues and its antibacterial properties against most microorganisms [2].

Biopure MTAD (Dentsply, Tulsa OK) is a mixture of tetracycline isomer (doxycycline) an acid (citric acid), and a detergent (Tween 80). When used as a root canal irrigant, MTAD has been reported to safely remove the smear layer and effectively eliminate Enterococcus faecalis. Studies have found $E$. faecalis to be a commonly recovered microbe in failing root canals [3].
The purpose of this investigation was to compare the antimicrobial efficacy of irrigation with Biopure MTAD versus irrigation with $5.25 \% \mathrm{NaOCl}$ in the root canals infected with E. faecalis.

\section{Materials and Methods}

\subsection{Sample Selection}

A total sample of 40 freshly extracted human, singlerooted lower premolar teeth of age 16-25 year were placed in distilled water. The soft tissue remnants and calculus on external root surface were removed mechanically with piezon Master 400 scaler (EMS, Swiss). All specimens were inspected to identify any defect or root fractures and to confirm the complete formation of apices under stereomicroscope (x10 magnification) (Motic, China).

Each tooth was decoronated at the level of cementenamel junction (CEJ) using a low-speed, water-cooled, diamond sectioning disc (Brasseler, Germany). Pulp tissue was removed with a barbed broach, then root canal patency was confirmed with No. 10 K-type file (Mani, Inc. Japan).

The working length of each root canal was determined by No-10 K-type file, which inserted inside the root canal under stereomicroscope at (x 10 magnification) until the tip of the file was just visible at the apical foramen and then subtracting $(1.0 \mathrm{~mm})$ from the measured length of the file [4]. 
Root canal irrigation was performed at the beginning of the instrumentation and after each instrument size with (2 $\mathrm{ml}$ ) of $2.5 \%$ sodium hypochlorite (NaOCL) solution [5].

At the end of the biomechanical preparation, the dentinal smear layer was removed from all specimens using (2 ml) of $17 \%$ ethylene diamine tetra-Acetic acid (EDTA) for 1 minute followed by $(2 \mathrm{ml})$ of $5.25 \%$ NaOCL solution $[4,6]$.

Finally all teeth inserted in the autoclave to be sterile and killed the remaining micro organism in the dentinal tubules of the root canal.

\subsection{Isolation of Microorganisms}

\subsubsection{Patient Selection}

Four patients with apical periodontitis of single root teeth as diagnosed by radiograph and clinical examination.

\subsubsection{Preparation of Access Opening}

Access cavity prepared initially with sterile turbine round and straight fissure bur until reach to pulp chamber roof. Before perforate the pulp chamber the tooth isolated with cotton roll and sucker tip then we used sterile handpiece large round bur to obtain the access opening.

Size 25, 30 and $35 \mathrm{k}$-file inserted in the canal as initial enlargement of the canal. Before root canal disinfection with irrigant solution to avoid killing of the microorganisms, a paper point size 25 inserted into the canal for (1) min. Paper point was removed and placed into brain heart infusion broth agar for $30 \mathrm{~min}$..

\subsubsection{Isolation of (Enterococcus feacalis)}

A loopful of inoculated brain heart infusion broth agar was spread on the surface of Enterococcus selective media using a cotton swab, then these inoculated media were incubated an aerobically using anaerobic jar at $37^{\circ} \mathrm{C}$ for 48 hrs. Enterococcus colonies appeared as reddish - pink color on the surface of the media.

\subsubsection{Isolation of Streptococcus mutans}

A loopful of inoculated brain heart infusion broth agar was spread on the surface of Mutans selective media using a cotton swab, then these inoculated media were incubated an aerobically using anaerobic jar at $37^{\circ} \mathrm{C}$ for 48 hrs. Mutans colonies appeared as bluish color on the surface of the media.

\subsection{Contamination of the Root Canal with $E$. faecalis and $S$. mutans}

After isolation of E. faecalis and S.mutans take a colony from the selective media to brain heart infusion broth and by sterile syringe this broth injected in the root canal then incubated an aerobically using anaerobic jar at $37^{\circ} \mathrm{C}$ for 24 hrs.

Now the irrigant solutions will be used (MTAD, NaOCl 5.25 , normal saline) the samples of MTAD irrigated with normal saline in the beginning and the used the MTAD as a final irrigant and left in the canal for $5 \mathrm{~min}$. according to manufacturer's instructions then the canal should be dried by sterile paper points, while the other groups irrigated with $5 \mathrm{ml}$ of $\mathrm{NaOCl} 5.25$ or normal saline and dried the canal by sterile paper point and by using sterile hand piece round bur which inserted inside the root canal and cut the internal wall the canal the dentine chips will be collected and transmitted to BHI broth agar and after 30 min. draw $0.1 \mathrm{ml}$ from this broth agar and add to $0.9 \mathrm{ml}$ (new not contaminated broth agar) and then from this new broth will draw $0.1 \mathrm{ml}$ and add to $0.9 \mathrm{ml}$ to produce $1 \mathrm{ml}$ from this agar inoculate the microorganism on the selective media and incubated at $37^{\circ} \mathrm{C}$ for $48 \mathrm{hrs}$, finally check the colonies forming unit CFU.

\section{Results}

Table 1. demonstrated the descriptive statistics of irrigant solutions which include mean, standard deviation (SD), standard error (SE), minimum and maximum value for (E. faecalis)

\begin{tabular}{|c|c|c|c|c|c|c|c|c|}
\hline \multirow{2}{*}{ material } & \multirow{2}{*}{$\mathrm{N}$} & \multirow{2}{*}{ Mean } & \multirow{2}{*}{ Std. Deviation } & \multirow{2}{*}{ Std. Error } & \multicolumn{2}{|c|}{ 95\% confidence interval for mean } & \multirow{2}{*}{ minimum } & \multirow{2}{*}{ maximum } \\
\hline & & & & & Lower Bound & Upper Bound & & \\
\hline MTAD & 6 & 4.3333 & 0.0334 & 0.0221 & -1.5724 & 11.5724 & 2.00 & 7.00 \\
\hline $\mathrm{NaOCl}$ & 6 & 11.3333 & 0.0521 & 0.0634 & 5.4151 & 17.9183 & 9.00 & 14.00 \\
\hline Distilled water & 6 & 62.6666 & 0.0112 & 0.0202 & 55.5476 & 70.4524 & 60.00 & 66.00 \\
\hline Total & 18 & 78.3332 & 0.0967 & 0.1057 & 5.3505 & 47.7606 & 2.00 & 66.00 \\
\hline
\end{tabular}

Table 2. One way ANOVA comparison among the materials revealed a statistically significant difference between groups $(\mathbf{p}<0.05)$

\begin{tabular}{|c|c|c|c|c|c|}
\hline & $\begin{array}{c}\text { Sum of } \\
\text { squares }\end{array}$ & Df & $\begin{array}{c}\text { Mean } \\
\text { square }\end{array}$ & F & Sig. \\
\hline $\begin{array}{c}\text { Between } \\
\text { groups }\end{array}$ & 6043.556 & 2 & 3021.778 & 405.910 & 0.000 \\
\hline Within groups & 44.667 & 6 & 7.444 & & \\
\hline Total & 6088.222 & 8 & & & \\
\hline
\end{tabular}

Table 3. Data of antibacterial activity against E.faecalis were analyzed by Duncan test as post hoc comparison that revealed a significant difference among their rigant solutions

\begin{tabular}{|c|c|c|c|c|}
\hline \multirow{2}{*}{ Material } & \multirow{2}{*}{$\mathrm{N}$} & \multicolumn{3}{|c|}{ Duncan's grouping* mean ** } \\
\cline { 3 - 5 } & & $\mathrm{A}$ & $\mathrm{B}$ & $\mathrm{C}$ \\
\hline MTAD & 6 & 5.0000 & & \\
\hline NaOCl & 6 & & 11.6667 & \\
\hline Distilled water & 6 & & & 63.0000 \\
\hline Sig. & & 1.000 & 1.000 & 1.000 \\
\hline
\end{tabular}

*Different letters mean significant results.

* mean of antibacterial activity.

Table 4. demonstrated the descriptive statistics of irrigant solutions which include mean, standard deviation (SD), standard error (SE), minimum and maximum value for (Streptococcus mutans)

\begin{tabular}{|c|c|c|c|c|c|c|c|c|}
\hline \multirow{2}{*}{ material } & \multirow{2}{*}{$\mathrm{N}$} & \multirow{2}{*}{ Mean } & \multirow{2}{*}{ Std. Deviation } & \multirow{2}{*}{ Std. Error } & \multicolumn{2}{|c|}{ 95\% confidence interval for mean } & \multirow{2}{*}{ minimum } & \multirow{2}{*}{ maximum } \\
\hline & & & & & Lower Bound & Upper Bound & & \\
\hline MTAD & 6 & 2.6666 & 0.0153 & 0.0133 & -1.4612 & 6.1279 & 1.00 & 4.00 \\
\hline $\mathrm{NaOCl}$ & 6 & 7.6666 & 0.0412 & 0.0255 & 3.5388 & 11.1279 & 6.00 & 9.00 \\
\hline Distilled water & 6 & 27.6666 & 0.0111 & 0.0112 & 24.4649 & 30.2018 & 26.00 & 28.00 \\
\hline Total & 18 & 37.9998 & 0.0676 & 0.0500 & 3.4770 & 21.1897 & 1.00 & 28.00 \\
\hline
\end{tabular}


Table 5. One way ANOVA comparison among the materials revealed a statistically significant difference between groups $(\mathbf{p}<0.05)$

\begin{tabular}{|c|c|c|c|c|c|}
\hline & $\begin{array}{c}\text { Sum of } \\
\text { squares }\end{array}$ & Df & $\begin{array}{c}\text { Mean } \\
\text { square }\end{array}$ & F & Sig. \\
\hline $\begin{array}{c}\text { Between } \\
\text { groups }\end{array}$ & 1050.000 & 2 & 525.000 & 262.500 & 0.000 \\
\hline Within groups & 12.000 & 6 & 2.000 & & \\
\hline Total & 1062.000 & 8 & & & \\
\hline
\end{tabular}

Table 6. Data of antibacterial activity against Strept. mutans were analyzed by Duncan test as post hoc comparison that revealed a significant difference among their rigant solutions

\begin{tabular}{|c|c|c|c|c|}
\hline \multirow{2}{*}{ Material } & \multirow{2}{*}{$\mathrm{N}$} & \multicolumn{3}{|c|}{ Duncan's grouping* mean ** } \\
\hline & & $\mathrm{A}$ & $\mathrm{B}$ & C \\
\hline MTAD & 6 & 2.3333 & & \\
\hline $\mathrm{NaOCl}$ & 6 & & 7.3333 & \\
\hline Distilled water & 6 & & & 27.3333 \\
\hline Sig. & & 1.000 & 1.000 & 1.000 \\
\hline
\end{tabular}

\section{Discussion}

The result from the positive control group showed that irrigation using distilled water is unable to render the root canal system free of bacteria and that the bacteria remained viable throughout the experiment.

MTAD showed a good antibacterial activity more than that of $\mathrm{NaOCl}$ against E.faecalis and this result in agreement with experiments carried out by $[1,3,7]$ proved that BioPure MTAD possesses superior bactericidal activity compared with $\mathrm{NaOCl}$.

Davis et al [8] and Krause et al. [9] in 2007 both proved MTAD to be more effective against $E$. faecalis than $\mathrm{NaOCl} 5.25 \%$. This study also demonstrates that MTAD is effective against arange of bacteria. Tayet al. [10] carried out a similar study that compared MTAD, $\mathrm{NaOCl}$ their results confirmed that MTAD was the most effective irrigant in eliminating E.faecalis.

Torabinejad et al. [11] has compared the effectiveness of MTAD and $\mathrm{NaOCl}$ (5.25\%) using the ZI technique and discovered their similar antibacterial action against $E$. faecalis.

On the other hand there are others studies in disagreement with our study [2,12], they found the $\mathrm{NaOCl}$ more effective than MTAD against $E$. faecalis.

These differences are probably in part explained by methodological differences such as alternative microbial sampling procedures or deviation from the manufacturer's usage recommendations when using BioPure MTAD [3].
The inconsistency in the results may be caused by differences in methodology and variance in strains tested. possibly due to the different concentration of $\mathrm{NaOCl}$, bacterial species and/or slightly different incubation conditions employed [7].

While the results of this study against $S$. mutans was the MTAD had strong antibacterial effect than $\mathrm{NaOCl}$ and there is no another study in agreement and / or disagreement with our result.

\section{References}

[1] Blerim Kamberi, Donika Bajrami, Miranda Stavileci :The Antibacterial Efficacy of Biopure MTAD in Root Canal Contaminated with Enterococcus faecalis. J Endod. 201; 34 (1): 55-58.

[2] Prabhakar J, Senthilkumar M, Priya MS: Evaluation of antimicrobial efficacy of herbal alternatives (Triphala and green tea polyphenols), MTAD, and 5\% sodium hypochlorite against Enterococcus faecalis biofilm formed on tooth substrate: an in vitro study. J Endod. 2010 Jan; 36 (1): 83-86

[3] Rakesh Mittal, Meenu G.: Comparative evaluation of the antimicrobial efficacy of MTAD, oxytetracycline, sodium hypochlorite and chlorhexidine against Enterococcus faecalis: An ex-vivo study. Saudi Endodontic Journal 2013 Vol. 2 Issue 2 (7074).

[4] Kocak M, Saglam O, Yaman S. Apical Leakage of Epiphany Root Canal Sealer Combined with Different Master Cones. European Journal of Dentistry; (2008); 2: pp. 91-95.

[5] Kumar N, Gokul P, Shivanna V. A Comparison of the Relative Efficacies of Hand and Rotary Instruments in the Removal of Guttapercha from the Root Canal during Retreatment Using Stereomicroscope-An In Vitro Study-. Journal of Endodontology; (2008); 4: pp. 5-11.

[6] Hu lsmann M, Peters OA, Dummer PMH. Mechanical preparation of root canals: shaping goals, techniques and means. Endod Topics (2005); 10 (19): pp 30-76.

[7] Kamberi B, Bajrami D, Stavileci M: The Antibacterial Efficacy of Biopure MTAD in Root Canal Contaminated with Enterococcus faecalis. J Endod. 2012; 30 (3): 73-76.

[8] Davis JM, Maki J, Bahcall JK. An in vitrocomparison of the antimicrobial effects of various endodontic medicaments on Enterococcus faecalis. JEndod 2007; 33: 567-9.

[9] Krause TA, Liewehr FR, Hahn CL. The antimicrobial effect of MTAD, sodium hypochlorite, doxycycline, and citric acid on Enterococcus faecalis. JEndod 2007; 33: 28-30.

[10] Tay FR, Hiraishi N, Schuster GS, Pashley DH, Loushine RJ, Ounsi HF, Grandini S, Yau JY, Mazzoni A, Donnelly A, King NM. Reduction in antimicrobialsubstantivity of MTAD after initial sodium hypochlorite irrigation. J Endod 2006; 32: 970-5.

[11] Torabinejad M, Shabahang S, Aprecio RM, Kettering JD. The antimicrobial effect of MTAD: an invitro investigation. J Endod 2003; 29: 400-3.

[12] Sandeep S, Sushma K, Shashi R: Comparison of antimicrobial efficacy of biopure MTAD and $2.5 \%$ sodium hypochlorite irrigation in infected root canals following single visit endodontics - An in vivo study. Braz. Dent. J 2007; 34 (2): 44-48. 